\title{
Meta-Analysis And Empirical Research Of Learning Style Theories In Higher Education: The Case Of Slovenia
}

Sandra Penger, University of Ljubljana, Slovenia

Metka Tekavčič, University of Ljubljana, Slovenia

Vlado Dimovski, University of Ljubljana, Slovenia

\begin{abstract}
Researchers have pointed out that students learn effectively in a harmonic environment and by using teaching aids which match the students' learning style preferences (Li et al., 2008). The learning styles literature is having a revival during last years. Although learning styles have been heavily researched (Coffield et al., 2004; Reynold \& Vince, 2007; Welsh et al., 2007; Hornyak et al., 2007; Herbert \& Stenfors, 2007; Sievers, 2007; Hyde, 2007; Kayes A.B., 2007; Kayes D. C., 2007; Garcia et al., 2007; Demirbas \& Demirkan, 2007; Armstrong \& Mahmud, 2008; Li et al., 2008), little is known about Slovenian students' learning styles, especially in the field of management education. The aim of study is to present and explore the learning styles of students enrolled in the course Economics of education at the University of Ljubljana, Faculty of Economics (FELU) in Slovenia. Another purpose is to better understand the different learning styles among management students in order to develop appropriate teaching strategies for improving management education at FELU. Additionally, the intention of this research is to develop a valid and reliable research questionnaire for further research processes and to set up research instruments as supportive mechanisms in management education and in the development curriculums and syllabuses of new courses. This study method included both a descriptive and an exploratory perspective. In the first part the qualitative meta-analysis method was used to overview the literature background. In the empirical part the factor analysis using the Principle Axes Factoring method was used to extract learning styles. The adapted versions of Honey and Mumford's (1992) Learning Style Questionnaire (LSQ) and Dunn \& Dunn's (2003) VAK Learning Style Theory (Coffield et al., 2004) were used as instruments in the questionnaire to determine Slovenian students' learning styles. Findings of the study outline, that for the educators in higher education institution, the challenge is to provide meta-cognitive support for students, enabling them to reflect not just on what they learn but also how and why.
\end{abstract}

Keywords: testing learning style theories, higher education, meta-analysis, factor analysis, Slovenia.

\section{INTRODUCTION}

"All life experiences hold the potential for learning. Some experiences result in learning, and some do not! (Merriam \& Caffarela, 1999; in Ellinger, 2007)

"One goal of management education is to help students organize experience in meaningful ways"

(Kayes, 2007)

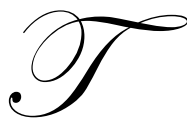

he concept of learning style has a broad meaning, in this research it is proposed and defined as individual's preferential focus on different types of information, the different ways of perceiving the information, and the understanding the information ( $\mathrm{Li}$ et al., 2008). The logic of lifelong learning suggests that students will become more motivated to learn by knowing more about their own strengths and weaknesses as learners. Consequently, if teachers can respond to individuals' learning style preferences, then the 
achievement rate is likely to rise and "learning to learn" skills and competencies of students may provide the foundation for the lifelong learning concept. Researchers have pointed out that students learn effectively in a harmonic environment and by using teaching aids which match the students' learning style preferences (Li et al., 2008). Although learning styles have been heavily researched (Duff \& Duffy, 2002; Lhori-Posey, 2003; Coffield et al., 2004; Reynold \& Vince, 2007; Welsh et al., 2007; Hornyak et al., 2007; Herbert \& Stenfors, 2007; Sievers, 2007; Hyde, 2007; Kayes A.B., 2007; Kayes D. C., 2007; Garcia et al., 2007; Demirbas \& Demirkan, 2007; Armstrong \& Mahmud, 2008; Li et al., 2008), little is known about Slovenian students' learning styles, especially in the field of management education. Consequently, the aim of this study/paper is to present, compare, validate and explore the learning styles of students enrolled in the course Economics of education during March and April 2008 in Slovenia at University of Ljubljana, Faculty of Economics (FELU) - Department of management and organization (http://www.ef.uni-lj.si/en/).

The purpose of this paper is to offer a better insight into the different learning styles among management students enrolled in the course Economics of Education in order to develop appropriate teaching and pedagogical strategies for improving management education at the Faculty of Economics in Ljubljana, Slovenia. The aim of this research is also to develop a valid and reliable research questionnaire for further research processes and to set up research instruments as supportive mechanisms in management education and in the development curriculums and syllabuses of new courses The adapted version of Honey and Mumford's (1992) Learning Style Questionnaire (LSQ) and Dunn \& Dunn's (2003) VAK Learning Style Theory (Coffield et al., 2004) were used as an instrument in the questionnaire to determine Slovenian students' learning styles. According to Coffield et al. (2004), one of the most widely-known theories assessed is the VAK learning styles model of Dunn and Dunn $(1992,1996)$. The Honey and Mumford's LSQ theory has also been widely applied in the fields of management training and education (Duff \& Duffy, 2002). The Honey and Mumford's (1992) LSQ model was developed to report management trainees' learning style preferences and has subsequently been applied to a wide range of subjects, including students in higher education (Duff \& Duffy, 2002).

Another research aim of this study is to evaluate the implications of tested theories with factor analysis for pedagogy and pedagogical implications within higher education institution in Slovenia. The research thesis of this study is that matching students' learning-style preferences with complementary course syllabus and instruction improved academic achievement and student attitudes toward learning. Based on the two selected learning theories Honey and Mumford's (1992) Learning Style Questionnaire theory (LSQ) and Dunn \& Dunn's (2003) VAK Learning Style theory, the research instrument in the form of a questionnaire was developed intended to answer the research question indicating the development of a valid and reliable measurement instrument to match and determine student' learning styles preferences within higher educational institution. The mission of management education is to create and disseminate knowledge to enable students' successful entry into the business world and offer a rewarding investment opportunity to the business community. The development of these new skills and knowledge requires a variety of teaching methods and learning strategies in order to match students' learning style preferences. Therefore, management teachers/lectures need an awareness of the learning style preferences of students in order to develop and utilize effective and efficient teaching and pedagogical strategies and methods. Recognizing students' learning styles allows educators (e.a. teachers, lecturers) to effectively lecture to a diverse population of students with different learning style preferences. An extended study based on this research would be recommended with a larger sample of management students in order to accumulate more comprehensive conclusions and broaden implications for management education. Being an effective teacher, implies matching individual learning style preferences among students with collective course syllabus in teaching strategies.

The composition of this study method is both a descriptive and exploratory. In the first part of the study the qualitative research method was used to overview the literature background of the study. In the empirical part of the study the factor analysis using the Principle Axes Factoring method - PAF was used to extract learning styles. The study sample included 63 students in a 3 year undergraduate program at the Faculty of Economics, University of Ljubljana. The instrument was administered to all course participants at the end of the course Economics of Education on 2nd of April 2008. The FELU has a long tradition in research and education as it was founded in 1946. Today, it is the largest faculty of the University of Ljubljana with almost 10,000 full-time and part-time undergraduate and graduate students. Development and modernisation of teaching and research work have been 
priorities at the FELU from its very beginning. In autumn 2005 the study programme was changed from $4+1$ study programmes into $3+2$ programmes in line with the Bologna Declaration and the prevailing pattern of business studies in Europe. In line with school reorganisation and modernisation the FELU was awarded EQUIS accreditation in 2006 which is the leading international system of quality assessment, improvement, and accreditation of higher education institutions in management and business administration.

This research paper has four main parts. First, it outlines the literature review and theoretical part of the study, summarizing learning styles continuum and taxonomy. Additionally, it classifies various types of learning styles theories and models according to the aim of the study. Second, it covers research framework and methodology, including data collection, sample characteristics, variables description, research instruments and data analysis. Third, it tests the learning styles theories using factor analysis and summarizes results of the empirical part of the study. Finally, it discusses the results and concludes by recognizing some limitations and by providing teaching/pedagogical implications and further research implications.

\section{LITERATURE REVIEW}

\subsection{Meta-Analysis Of Learning Styles}

Many studies of the learning styles have been conducted in the field of higher education (Duff \& Duffy, 2002; Lohri-Posey, 2003; Coffield et al., 2004; Demirbas \& Demirkan, 2007; Li et al., 2008). Educationalists introduced the concept of learning style as a "description of the attitudes and behaviours that determine our preferred way of learning" (Honey \& Mumford, 1992; 2001). In Figure 1 we present through meta-analysis the continuum of learning styles families (theories) (Coffield at al., 2004).

Figure 1: Meta-analysis review of learning styles families (theories)

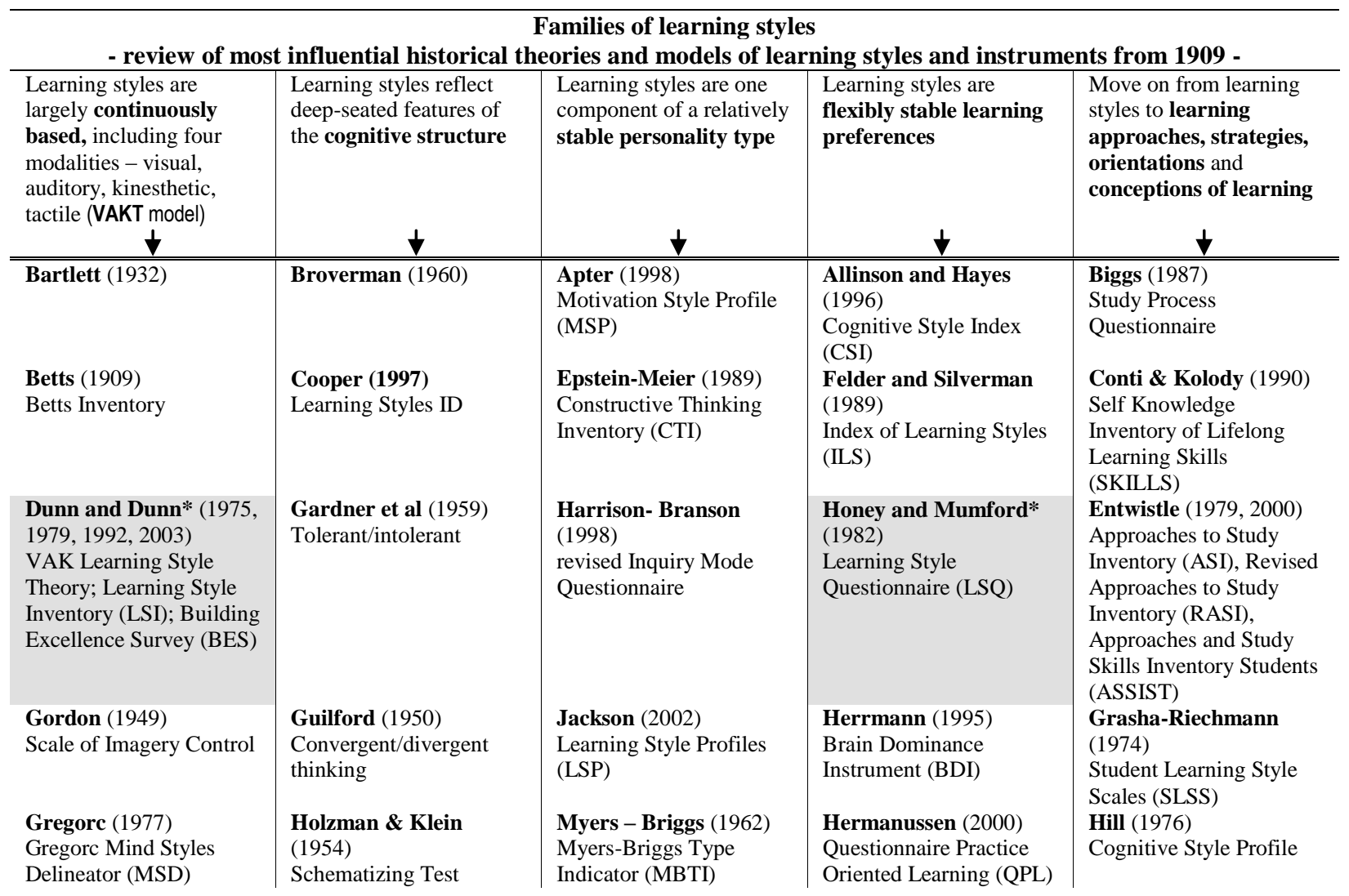




\begin{tabular}{|c|c|c|c|c|}
\hline \multicolumn{5}{|c|}{ Families of learning styles } \\
\hline $\begin{array}{l}\text { Marks (1973) } \\
\text { Marks Vividness of } \\
\text { Visual Imagery } \\
\text { Questionnaire } \\
\text { Paivio (1971) } \\
\text { Individual Difference } \\
\text { Questionnaire (IDQ) } \\
\text { Richardson (1977) } \\
\text { Verbaliser Visualiser } \\
\text { Questionnaire } \\
\text { Scheehan (1967) } \\
\text { Shortened Betts } \\
\text { Inventory } \\
\text { Torrance (1990) } \\
\text { Style of Learning and } \\
\text { Thinking }\end{array}$ & $\begin{array}{l}\text { Hunt (1978) } \\
\text { Paragraph Completion } \\
\text { Method } \\
\text { Kagen (1967) } \\
\text { Matching Familiar } \\
\text { Figures Test } \\
\text { Kogan (1973) } \\
\text { Sorting Styles into Types } \\
\text { Messick (1976) } \\
\text { Analytic / non-analytic } \\
\text { conceptualizing } \\
\text { Prettigrew (1958) } \\
\text { Scale of Cognitive Style } \\
\text { Riding (1991) } \\
\text { Cognitive Style Analysis } \\
\text { (CSA) }\end{array}$ & $\begin{array}{l}\text { Miller (1991) } \\
\text { Personality typology: } \\
\text { cognitive, affective, } \\
\text { conative } \\
\text { Witkin (1962) } \\
\text { Group Embedded Figure } \\
\text { Test (GEFT) }\end{array}$ & $\begin{array}{l}\text { Kolb (1976, 1985, 1999) } \\
\text { Learning Style Inventory } \\
\text { (LSI); Revised Learning } \\
\text { Style Inventory (R-LSI); } \\
\text { LSI Version } 3 \\
\text { Kirton (1989) } \\
\text { Kirton Adaption } \\
\text { Innovation Inventory } \\
\text { (KAI) } \\
\text { McCarthy (1987) } \\
\text { 4MAT }\end{array}$ & $\begin{array}{l}\text { Schmeck (1977) } \\
\text { Inventory of Learning } \\
\text { Processes } \\
\text { Vermunt (1996) } \\
\text { Inventory of Learning } \\
\text { Styles (ILS) } \\
\text { Weinstein, } \\
\text { Zimmerman, Palmer } \\
\text { (1988) } \\
\text { Learning and Study } \\
\text { Strategies Inventory }\end{array}$ \\
\hline
\end{tabular}

Source: Adapted from Coffield, Moseley, Hall \& Ecclestone, 2004; Reynolds \& Vince, 2007; Li et al., 2008.

*the shaded boxes - (Dunn \& Dunn's VAK model and Honey and Mumford's LSQ theory were used for the analysis in this study.

One of the key differences between the various theories or families (Coffield et al., 2004) of learning styles is the extent to which they are thought to be stable, or fixed ('hard wired') into learners' minds. Some theorists believe that learning styles are rooted in fixed genetic traits, while others emphasize the influence on how learners gain of experience, the environment and curriculum design. Keefe (1979) defined a learning style as "characteristics cognitive, affective and psychological behaviors that serve as relatively stable indicators of how learners perceive, interact with, and respond to the learning environment". Duff and Duffy's (2002) definition of learning style outlines that learning style is the composite of characteristics of cognitive, affective, and psychological factors that serves as an indicators of how an individual interacts with and responds to the learning environment. The report on continuum of learning styles view most influential theories and models of learning styles and their literature grouped into five families/groups according to Coffield's classification. Coffield et al. (2004) compare the 13 theories of learning styles based on the qualitative meta-analysis on four criteria as internal consistency, test-retest reliability, constructive and predictive reliability.

\subsection{Meta-Analysis Of Recent Research On Learning Styles}

The chronological meta-analysis taxonomy (see Figure 2) outlines the most influential research studies and research construct within learning style categorization from 2000 till present, 2008. Upon reviewing the literature on learning styles the intense rate and growing interest is recognized (Coffield et al. 2004). The learning styles literature has had a revival during last years, especially in the first decade of $21^{\text {st }}$ century (Alban \& Metcalfe 2002; Duff \& Duffy, 2002; Dunn \& Griggs, 2003; Kayes, 2003; Loo, 2004). To management and teachers, learning styles theories have long been an important, although by no means dominant, part of educational approach (Reynolds \& Vince, 2007). Since 2007 and 2008 there has been an increasing interest in the potential of experiential learning (Reynolds \& Vince, 2007; Argyris, 2007; Welsh et al., 2007; Hornyak et al., 2007; Herbert \& Stenfors, 2007; Sievers, 2007; Hyde, 2007; Kayes A. B., 2007; Kayes D. C., 2007 and Armstrong \& Mahmund, 2008).

The concept of learning styles is embedded in different academic literature and researched from different approaches, including intelligent learning systems (Laureano-Cruces et al., 2006), a genetic algorithm approach to students' learning styles (Yannibelli et al., 2006), web-based education perspective on learning style (Garcia et al., 
2007), learning about and through aesthetic experience (Welsh et al., 2007), use of business case studies in learning process (Duff et al., 2008), problem-solving strategies within learning styles (Metallidou \& Platsidou, 2008), preferred learning styles (Peters et al., 2008) and adaptive learning system perspective of learning styles (Tseng et al., 2008).

Accordingly to the growing interests of learning styles theories and instruments in higher education and management education ( $\mathrm{Li}$ et al., 2007; Lhori-Posey, 2003; Cuthbert, 2005; Garcia et al., 2007; Demirbas \& Demirkan, 2007), the concept of organizational learning is emerging among business entities and organizational learning companies (Škerlavaj et al., 2007; Škerlavaj \& Dimovski, 2007; Dimovski et al., 2008). According to Škerlavaj \& Dimovski (2007), organizational learning has emerged as one of the most researched phenomenon in organizational sciences. Therefore, it comes as no surprise that the concept of organizational learning is founded on a wide assortment of theoretical assumptions which should be viewed as complementary to each other in the understanding of the organizational learning field and filed of learning styles.

Figure 2: Meta-analysis through chronological taxonomy of recent research on learning styles

\begin{tabular}{|c|c|c|c|}
\hline \multicolumn{4}{|c|}{ Chronological taxonomy of recent research into learning styles and (organizational) learning } \\
\hline $2000-2004$ & $2005-2006$ & 2007 & 2008 \\
\hline $\begin{array}{l}\text { Alban \& Metcalfe (2002) } \\
\text { - disorder type behavior among } \\
\text { undergraduates }\end{array}$ & $\begin{array}{l}\text { Cuthbert } \\
\text { - student learning process: } \\
\text { learning styles or learning } \\
\text { approaches } \\
\text { - learning situation } \\
\text { - teaching in higher education }\end{array}$ & $\begin{array}{l}\text { Argyris } \\
\text { - double loop learning in a } \\
\text { classroom setting }\end{array}$ & $\begin{array}{l}\text { Armstrong \& Mahmud } \\
\text { - experiential learning and the } \\
\text { acquisition of managerial tacit } \\
\text { knowledge } \\
\text { - Kolb's learning style inventory }\end{array}$ \\
\hline $\begin{array}{l}\text { Dart et al (2000) } \\
\text { - students' conceptions of } \\
\text { learning }\end{array}$ & $\begin{array}{l}\text { Laureano-Cruces, Ramrez- } \\
\text { Rodrguez, de Arriaga \& } \\
\text { Escarela-Perez } \\
\text { - intelligent learning systems } \\
\text { (ILSs) }\end{array}$ & $\begin{array}{l}\text { Champoux } \\
\text { - experiential learning in the on- } \\
\text { line environment }\end{array}$ & $\begin{array}{l}\text { Alkhasawneh, Mrayyan, } \\
\text { Docherty, Alashram \& Yousef } \\
\text { - problem-based learning (PBL): } \\
\text { assessing students' learning } \\
\text { preferences }\end{array}$ \\
\hline $\begin{array}{l}\text { Duff \& Duffy (2002) } \\
\text { - Kolb's learning style } \\
\text { questionnaire, academic } \\
\text { performance } \\
\text { - Honey \& Mumford's learning } \\
\text { style questionnaire }\end{array}$ & $\begin{array}{l}\text { Yannibelli, Godoy \& Amandi } \\
\text { - a genetic algorithm approach } \\
\text { to recognize students' learning } \\
\text { styles } \\
\text { - computer-based educational } \\
\text { systems }\end{array}$ & $\begin{array}{l}\text { Demirbas \& Demirkan } \\
\text { - learning styles and academic } \\
\text { performance } \\
\text { - using Kolb's experiential } \\
\text { learning theory (ELT) }\end{array}$ & $\begin{array}{l}\text { Dimovski, Škerlavaj, Kimman } \\
\text { \& Hernaus } \\
\text { - organizational learning } \\
\text { processes, Slovenia, Croatia, } \\
\text { Malaysia }\end{array}$ \\
\hline $\begin{array}{l}\text { Dunn \& Griggs (2003) } \\
\text { - Synthesis of the Dunn and } \\
\text { Dunn learning style model } \\
\text { research }\end{array}$ & & $\begin{array}{l}\text { Garcia, Amandi, Schiaffino \& } \\
\text { Campo } \\
\text { - detecting students' learning } \\
\text { styles } \\
\text { - web based education }\end{array}$ & $\begin{array}{l}\text { Duff, Dobie \& Guo } \\
\text { - the use of case studies and } \\
\text { learning styles in accounting } \\
\text { education in New Zeland } \\
\text { - use of business case studies } \\
\text { (BCS) }\end{array}$ \\
\hline $\begin{array}{l}\text { Kayes (2002) } \\
\text { - experiential learning theory } \\
\text { and its critics: the role of } \\
\text { experience in management } \\
\text { learning and education }\end{array}$ & & $\begin{array}{l}\text { Hornyak, Green \& Heppard } \\
\text { - implementing experiential } \\
\text { learning }\end{array}$ & $\begin{array}{l}\text { Filippidis \& Tsoukalas } \\
\text { - Felder-Silverman's learning style } \\
\text { theory } \\
\text { - adaptive educational system }\end{array}$ \\
\hline $\begin{array}{l}\text { Lhori-Posey (2003) } \\
\text { - determining learning style } \\
\text { preferences of students }\end{array}$ & & $\begin{array}{l}\text { Herbert \& Stenfors } \\
\text { - management education and } \\
\text { experiential learning methods }\end{array}$ & $\begin{array}{l}\text { Graf, Lin \& Kinshuk } \\
\text { - relationship between learning } \\
\text { styles and cognitive traits } \\
\text { - Felder-Silverman learning style } \\
\text { model } \\
\text { - working memory capacity }\end{array}$ \\
\hline $\begin{array}{l}\text { Loo (2004) } \\
\text { - Kolb's learning style and } \\
\text { learning preferences }\end{array}$ & & $\begin{array}{l}\text { Kayes } \\
\text { - power and experience } \\
\text { - management education } \\
\text { - conversational learning } \\
\text { Reynolds \& Vince } \\
\text { - experiential learning and } \\
\text { management education }\end{array}$ & $\begin{array}{l}\text { Li, Chen \& Tsai } \\
\text { - learning styles in Taiwan (higher } \\
\text { education) } \\
\text { - using Myers-Briggs Type } \\
\text { Indicator } \\
\text { Metallidou \& Platsidou } \\
\text { - the psychometric properties of } \\
\text { Kolb's LSI-1985 in a Greek } \\
\text { sample }\end{array}$ \\
\hline
\end{tabular}




\begin{tabular}{|c|c|c|c|}
\hline \multicolumn{4}{|c|}{ Chronological taxonomy of recent research into learning styles and (organizational) learning } \\
\hline 2000-2004 & 2005-2006 & 2007 & 2008 \\
\hline & & $\begin{array}{l}\text { Škerlavaj \& Dimovski } \\
\text { - network perspective of intra- } \\
\text { organizational learning } \\
\text { Škerlavaj, Indihar- } \\
\text { Štemberger, Škrinjar, } \\
\text { \&Dimovski } \\
\text { - organizational learning culture } \\
\text { in Slovenian companies } \\
\text { Verpoorten, Poumay \& } \\
\text { Leclercq } \\
\text { - eight Learning Events Model } \\
\text { - pedagogical framework } \\
\text { Welsh, Dehler \& Murray } \\
\text { - learning about and through } \\
\text { aesthetic experience }\end{array}$ & $\begin{array}{l}\text { - meta-cognitive knowledge } \\
\text { - problem-solving strategies } \\
\text { Peters, Jones \& Peters } \\
\text { - preferred learning styles' and } \\
\text { their relationship with grades for } \\
\text { students undertaking } \\
\text { Tseng, Chu, Hwang, \& Tsai } \\
\text { - adaptive learning system } \\
\text { - computer-assisted learning }\end{array}$ \\
\hline
\end{tabular}

Source: Authors; adapted from the research papers and publications indicated in the figure, 2008.

\subsection{Dunn \& Dunn's Learning Style Theory}

Based on the two selected learning theories - Honey and Mumford's (1992) Learning Style Questionnaire (LSQ) and Dunn \& Dunn's (2003) VAK Learning Style Theory, the research instrument was developed helping answer the research question indicating the development of an valid and reliable measurement instrument to match and determine student' learning styles preferences within higher educational institution. In this study two learning style theories were applied and explored in the questionnaire. The objective of the research was to test whether students from Ljubljana's Faculty of Economics follow theoretical assumptions of presented learning styles theories as they are conceptualized in the Figure 3 and Figure 4.

For over 35 years, the Dunns, Rita and Kenneth, have developed an extensive research programme designed to improve the instruments that derive from their model of learning style preferences. The Dunn and Dunn's VAK learning style model uses the three main sensory receivers: Visual, Auditory, and Kinesthetic to determine the dominant learning style (Figure 3). The model is sometimes known as VAKT (Visual, Auditory, Kinesthetic, \& Tactile; Cofield et al., 2004). Learners use all three modalities to receive and learn new information and experiences. However, according to the theory, one or two of these receiving styles is normally dominant. This dominant style defines the best way for a person to learn new information by filtering what is to be learned. This style may not always be the same for some tasks. The learner may prefer one style of learning for one task, and a combination of others for a different task. While there is some evidence for modality specific strengths and weaknesses (Rourke et al., 2002), what has not been established is matching the instructional style to individual learning strength improves their learning abilities. Constantinidou and Baker (2002) found that visual presentation through the use of pictures was advantageous for all adults, irrespective of a high or low learning-style preference for visual images. Indeed, it was especially advantageous for those with a strong preference for verbal processing. An important principle in the Dunn and Dunn's model is the idea that students' potential and achievement are heavily influenced by relatively fixed traits and characteristics (Dunn, 2001; Dunn, 2003; Dunn \& Griggs, 2003). This raises a fundamental educational question, namely, how far individuals can remedy their low preferences or change their preferences altogether. The recent overview of the model (Coffield et al., 2004) contains the claim that 'the learning styles of students changed substantially as they matured from adolescence into adulthood. It seems, that some change in learning styles takes place over time. 
Figure 3: Dunn \& Dunn's learning style theory (VAK) - recognizes three ways of information perception:

\begin{tabular}{|c|c|}
\hline Perception & $\begin{array}{rr}\text { Description/Characteristics } \\
\end{array}$ \\
\hline V: Visual - Seeing & $\begin{array}{l}\text { Mind sometimes strays during verbal activities } \\
\text { Observes, rather than talks or acts; may be quiet by nature } \\
\text { Organized in approach to tasks } \\
\text { Likes to read } \\
\text { Usually a good speller } \\
\text { Memorizes by creating mental images } \\
\text { Thinks in pictures } \\
\text { Easily put off by visual distractions } \\
\text { Finds verbal instructions difficult } \\
\text { Remembers faces } \\
\text { Strong on first impressions } \\
\text { Likes drawing and doodling, may have good handwriting } \\
\text { Enjoys using color } \\
\text { Notices details } \\
\text { Often a quick thinker } \\
\text { May focus on the 'big picture' and use advanced planning }\end{array}$ \\
\hline A: - Auditory - Hearing & $\begin{array}{l}\text { Talks to self aloud } \\
\text { Outgoing by nature } \\
\text { Whispers to self while reading, may hum or sing while working } \\
\text { Likes to be read to } \\
\text { May be particular about the exact choice of words } \\
\text { Memorizes by steps in a sequence } \\
\text { Very aware of rhythm } \\
\text { Easily distracted by noises } \\
\text { May have difficulty with written instructions } \\
\text { Remembers names } \\
\text { May assess people by the sound of their voice } \\
\text { Enjoys music and the sounds of words } \\
\text { Enjoys talking and listening } \\
\text { Can remember - and often mimic - speech by picking up rhythm of the sentence } \\
\text { May need time to think (i.e. discuss it with myself) } \\
\text { May assess a situation on 'how it sounds' to them }\end{array}$ \\
\hline K: Kinaesthetic - Doing & $\begin{array}{l}\text { In motion most of the time/fidgety } \\
\text { Outgoing by nature; expresses emotions by physical means } \\
\text { Taps pencil or foot/fiddles with objects while studying } \\
\text { Reading is not a priority } \\
\text { May find spelling difficult } \\
\text { Likes to solve problems by physically working through them } \\
\text { Very good body control, good timing and reflexes } \\
\text { Is affected by touch or lack of it } \\
\text { Likes physical rewards } \\
\text { Remembers what they have done rather than seen/heard } \\
\text { May assess people and situations by what 'feels right' } \\
\text { Enjoys handling objects } \\
\text { Enjoys doing activities } \\
\text { Likes to use gestures and touch people while talking to them } \\
\text { May need time to think (i.e. process the actions involved) } \\
\text { Will try new things - likes to get involved }\end{array}$ \\
\hline
\end{tabular}

Source: Authors; Adapted from Coffield et al., 2004; Dunn \& Griggs, 2003; Dunn, 2001; Dunn, 2003.

\subsection{Honey And Mumford's Learning Style Questionnaire (LSQ) Theory}

Honey and Mumford spent four years experimenting with different approaches to assessing individual differences in learning preferences before producing the Learning Styles Questionnaire in 1982 (Coffield et al. 2004). Honey and Mumford's learning style questionnaire has been widely applied in the fields of management training and education. Honey and Mumford's learning style questionnaire, known as Learning Style Questionnaire (LSQ) Theory has been widely used as an instrument of detecting students' learning style in higher education (Duff \& Duffy, 2002; Coffield et al., 2004) and management practices (Allinson \& Hayes, 1990). Honey and Mumford's 
Learning Style Questionnaire (LSQ) has been proposed as an alternative for Kolb's Experiential Learning Style Model (ELM) and a later refined version (LSI-1985) (Duff \& Duffy, 2002). The LSQ is designed to probe the relative strengths of four different learning styles (Honey \& Mumford, 1992): Activist, Reflector, Theorist and Pragmatist. Honey and Mumford's intention is that learners should become proficient in all four stages of the learning cycle. The authors are keen to emphasise that 'no single style has an overwhelming advantage over any other. Each has strengths and weaknesses but the strengths may be especially important in one situation, but not in another'. These four styles correspond approximately to those suggested by Kolb's $(1976 ; 1999)$ Experiential Learning Model (ELM): active experimentation (Activist), reflective observation (Reflector), abstract conceptualisation (Theorist), and concrete experience (Pragmatist).

Figure 4: Honey and Mumford's learning style questionnaire (LSQ) - recognizes four types of styles

\begin{tabular}{|c|c|c|}
\hline Learning style & $\begin{array}{l}\text { Description } \\
\end{array}$ & Characteristics \\
\hline Reflectors & $\begin{array}{l}\text { Reflectors like to stand back to ponder experiences and observe them from } \\
\text { many different perspectives. They collect data, both first hand and from } \\
\text { others, and prefer to think about it thoroughly before coming to any } \\
\text { conclusion. The thorough collection and analysis of data about experiences } \\
\text { and events is what counts so they tend to postpone reaching definitive } \\
\text { conclusions for as long as possible. Their philosophy is to be cautious. They } \\
\text { are thoughtful people who like to consider all possible angles and } \\
\text { implications before making a move. }\end{array}$ & $\begin{array}{ll}\text { - } & \text { Careful } \\
\text { - } & \text { Good listener } \\
\text { - } & \text { Holds back from participation } \\
\text { - } & \text { Does not jump to conclusions } \\
\text { - } & \text { Slow to decide } \\
\text { - } & \text { Thorough and thoughtful }\end{array}$ \\
\hline Theorists & $\begin{array}{l}\text { Theorists adapt and integrate observations into complex but logically sound } \\
\text { theories. They think problems through in a vertical, step-by-step logical } \\
\text { way. They assimilate disparate facts into coherent theories. They tend to be } \\
\text { perfectionists who won't rest easy until things are tidy and fit into a rational } \\
\text { scheme. They like to analyze and synthesize. They are keen on basic } \\
\text { assumptions, principles, theories models and systems thinking. Their } \\
\text { philosophy poses rationality and logic. "If it's logical it's good". Questions } \\
\text { they frequently ask are: "Does it make sense?" "How does this fit with that?" } \\
\text { "What are the basic assumptions?" They tend to be detached, analytical and } \\
\text { dedicated to rational objectivity rather than anything subjective or } \\
\text { ambiguous. }\end{array}$ & 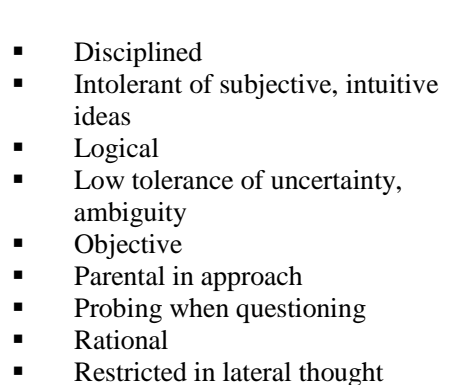 \\
\hline Activists & $\begin{array}{l}\text { Activists involve themselves fully and without bias in new experiences. } \\
\text { They enjoy the here and now and are happy to be dominated by immediate } \\
\text { experiences. They are open-minded, not skeptical, and this tends to make } \\
\text { them enthusiastic about anything new. Their philosophy is "I'll try anything } \\
\text { once". They tend to act first and consider the consequences afterwards. } \\
\text { Their days are filled with activity. They tackle problems by brainstorming. } \\
\text { As soon as the excitement from one activity has died down they are busy } \\
\text { looking for the next. They tend to thrive on the challenge of new } \\
\text { experiences but are bored with implementation and longer term } \\
\text { consolidation. }\end{array}$ & $\begin{array}{l}\text { - } \text { Flexible } \\
\text { - } \text { Gets bored with consolidation } \\
\text { - } \text { Open minded } \\
\text { - } \quad \text { Optimistic about change } \\
\text { - } \quad \text { pushes into action without } \\
\text { - Takes immediate obvious action } \\
\text { - } \quad \text { Takes unnecessary risks } \\
\text { - }\end{array}$ \\
\hline Pragmatists & $\begin{array}{l}\text { Pragmatists are keen on trying out ideas, theories and techniques to see if } \\
\text { they work in practice. They positively search out new ideas and take the first } \\
\text { opportunity to experiment with applications. They are the sort of people who } \\
\text { return from management courses brimming with new ideas that they want to } \\
\text { try out in practice. They like to get on with things and act quickly and } \\
\text { confidently on ideas that attract them. They tend to be impatient with } \\
\text { ruminating and open ended discussions. They are essentially practical, } \\
\text { down-to-earth people who like making practical decisions and solving } \\
\text { problems. }\end{array}$ & $\begin{array}{l}\text { - } \quad \text { Businesslike - gets to the point } \\
\text { - } \quad \text { Impoes not like theory } \\
\text { - } \quad \text { Keen to test things out in practice } \\
\text { - } \quad \text { Practical, down to earth, realistic } \\
\text { - } \quad \text { Rejects ideas without clear } \\
\text { - } \quad \text { Seizplication } \\
\text { - } \quad \text { Task and technique focused }\end{array}$ \\
\hline
\end{tabular}

Source: Authors. Adapted from Honey \& Mumford, 1992; Coffield et al., 2004; 


\section{RESEARCH FRAMEWORK AND METHODOLOGY}

\subsection{Data Collection, Sample Characteristics And Variables Description}

The interviewed students attend the second and third year study ending with the Bachelor's Degree. Data were collected in April 2008 at the Faculty of Economics, University of Ljubljana during the course Economics of Education. The sample consists of 63 students at the Faculty of Economics, University of Ljubljana. The convenience sampling was used for this purpose as, this being the first such research in national higher educational system, this was to a certain level an exploratory research setting a base for further research in this field. Students were anonymously interviewed using paper questionnaires. The questionnaire consisted of 27 questions/variables, of which 2 were socio-demographic variables (gender and year of study) and the remaining 25 variables describing interviewees' learning attitudes.

\subsection{Research Instruments}

The research questionnaire was developed for the purpose of this research. The objective of the analysis was to find/confirm different learning approaches used by students. Besides, the research should help developing valid and reliable research questionnaire for further research processes. The questionnaire is an adapted combination of two questionnaires supporting both applied theories - Honey and Mumford's and Dunn \& Dunn's Learning Style theories. The adaptation was chosen following the preliminary discussions with 3 experts from the field of research. The main criterion for adapting the questionnaires (i.e. reducing the number of questions from usually used questionnaires) was to reduce the number of variables to the level that allows statistical analysis with relatively small sample. The questions applied were those that, according to expert judgment, best described individual learning characteristics. Besides, the intuitive argument for rationalizing the questionnaire is that in situations where questionnaires that are too long or interviewees are not aware of the consequences or future uses of the questionnaires, interviewees tend to choose answers arbitrarily instead of thinking carefully about them. Thus, the results obtained can be inaccurate and may not reflect the actual learning styles. The learning approaches should differentiate according to different classifications. Two most influential theories on learning style that were integrated into this research are (1) the Dunn \& Dunn's (2003) learning style theory, which defines the classification according to use of distinct senses when learning (the theory recognizes seeing - visual, hearing - auditory and doing - kinaesthetic types of learning approach), and (2) the Honey and Mumford's (1992) learning style questionnaire (LSQ) theory (the theory recognizes reflectors, theorists, activists, pragmatists as typical learning styles). According to these two theories, two groups of variables were used that are supposed to measure the learning styles used among the interviewed students (Table 1 and Table 2). All variables measuring learning styles were measured using the following ordinal scale: (1) disagree strongly; (2) disagree; (3) neutral; (4) agree; (5) agree strongly. Variables that are in italic style in both tables were excluded from further analysis because of inconsistency with other variables measuring similar learning approach ${ }^{1}$

Table 1: Group of variables measuring styles according to the Dunn \& Dunn's learning style theory

\begin{tabular}{|c|c|}
\hline Variables & Description of Variables \\
\hline $\mathrm{Vp} 1$ & I prefer written instructions given by the lecturer. \\
\hline $\mathrm{Vp} 2$ & I prefer spoken instructions given by the lecturer. \\
\hline Vp3 & Asking questions and discussing are the most effective way to learn the topic. \\
\hline$V p 4 *$ & Reading instructions can best help me learn the topic. \\
\hline $\operatorname{Vp} 5 *$ & I prefer using electronic media (internet, email etc.). \\
\hline Vp6 & I can easily find the solution when given the spoken instructions. \\
\hline Vp7 & Topics are best explained when presented on paper/transparency/blackboard. \\
\hline Vp8 & Practical examples are the most effective learning tool. \\
\hline Vp9 & I learn most when doing practical simulation of presented topics. \\
\hline Vp10 & I learn more easily when the lecturer has practical experiences. \\
\hline
\end{tabular}

Source: Authors.

*Variables that are in italic style in both tables were excluded from further analysis because of inconsistency with other variables measuring similar learning approach (see Ferligoj et al., 2004 for methodological explanation).

\footnotetext{
${ }^{1}$ The inconsistency is presumably the result of question misunderstanding (see Ferligoj et al., for methodological explanation).
} 
Table 2: Group of variables measuring styles according to the Honey and Mumford's learning style theory

\begin{tabular}{|c|c|}
\hline Variables & Description of Variables \\
\hline Vs1 & My way of thinking is very flexible, I am open-minded and always ready to experiment. \\
\hline$V s 2 *$ & I usually observe the problem from many different perspectives. \\
\hline Vs3 & I work and study thoroughly and thoughtfully. \\
\hline Vs4 & I learn using basic assumptions, principles, theories models and systems thinking. \\
\hline Vs5 & I like involving myself with others and being where the centre of activities is. \\
\hline Vs6 & $\begin{array}{l}\text { The thorough collection and analysis of data about experiences and events is what counts when reaching } \\
\text { definitive conclusions. }\end{array}$ \\
\hline Vs7 & I like to work in groups so I can bounce ideas around and try out as many ideas as possible. \\
\hline$V s 8^{*}$ & I am bored with implementation and longer term consolidation. \\
\hline Vs9 & I seek to centre all activities around myself. \\
\hline Vs10 & I like to analyse and synthesise, I like to adapt and integrate observations into theories and frameworks. \\
\hline Vs11 & The precondition for reaching a conclusion is the meticulous collection of data and its analysis. \\
\hline Vs12 & I like to immerse myself in as many experiences and activities as possible. \\
\hline Vs13 & I am practical, down to earth, realistic. \\
\hline Vs14 & I am a practical, down-to-earth person who likes making practical decisions and solving problems. \\
\hline Vs15 & I like to get on with things and act quickly and confidently on ideas that attract me. \\
\hline
\end{tabular}

Source: Authors.

\subsection{Data Analysis - Factor Analysis}

Data were analyzed using the Statistical Package for the Social Sciences (SPSS 16.0). An alpha level of 0,05 was used as margin of statistical significance(Coakes \& Steed, 2003). The factor analysis using the Principle Axes Factoring method - PAF was used to extract learning approaches (Miller et al., 2002; Coakes \& Steed, 2003). The essential purpose of factor analysis is to describe the variation among many variables in terms of a few underlying but unobservable random variables called factors. Factor analysis is a data reduction statistical technique that allows simplifying the correlational relationship between a set of continuous variables (Miller et al., 2002). Factor analysis is a generic term for a family of statistical techniques concerned with the reduction of a set of observable variables in terms of a small number of latent factors. It has been developed primarily for analyzing relationships among a number of measurable entities (such as survey items or test scores). The underlying assumption of factor analysis is that there exists a number of unobserved latent variables (or "factors") that account for the correlations among observed variables, such that if the latent variables are partialled out or held constant, the partial correlations among observed variables all become zero. In other words, the latent factors determine the values of the observed variables. One of the most frequently used techniques for factor extraction is the Principal Factor Method, where factors are extracted in such a way that each factor accounts for the maximum possible amount of the variance contained in the set of variables being factored (Miller et al., 2002).

The applicability of factor analysis was tested using Kaiser-Meyer-Olkin Measure of Sampling Adequacy (KMO measure) and Bartlett's Test of Sphericity ( $\chi^{2}$ test). Both tests confirmed the applicability of factor analysis ${ }^{2}$ for both groups of variables (see Table 3). The KMO measures the sampling adequacy which should be greater than 0.5 for a satisfactory factor analysis to proceed (Coakes \& Steed, 2003). Another indicator of the strength of the relationship among variables is Bartlett's test of sphericity. Bartlett's test of sphericity is used to test the null hypothesis that the variables in the population correlation matrix are uncorrelated. The observed significance level is .0000. It is small enough to reject the hypothesis. It is concluded that the strength of the relationship among variables is strong. In both factor analyses the varimax rotation was performed. Varimax rotation is an orthogonal rotation of the factor axes to maximize the variance of the squared loadings of a factor on all the variables. Each factor will tend to have either large or small loadings of any particular variable. A varimax solution yields results which make it as easy as possible to identify each variable with a single factor. This is the most common rotation option (Coakes \& Steed, 2003).

${ }^{2}$ The applicability criteria was KMO measure being $>0,6$ and $\chi^{2}$ test statistically significant (Miller et al., 2002). 
Table 3: KMO and Bartlett's Test

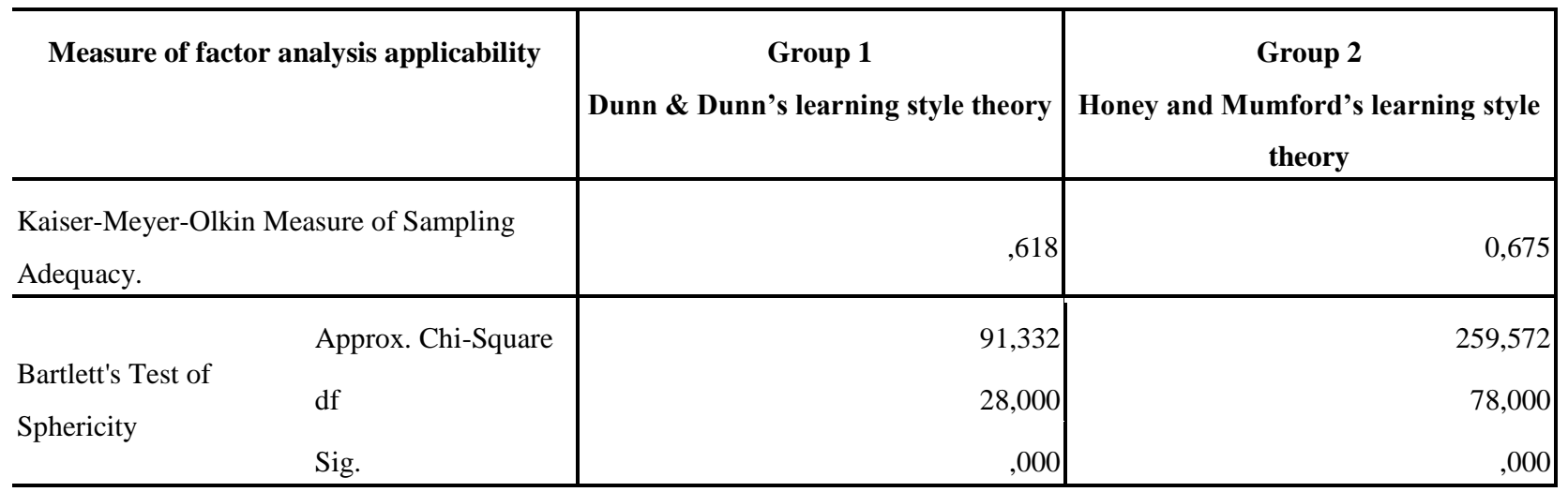

Source: Authors.

\section{RESULTS}

\subsection{Factor Analyses Results}

The scree plots (Figure 5 and Figure 6) and tables (Table 4 and Table 5) shown below for both analyses confirm, using the eigenvalues-greater-than-one rule, the extraction of three factors for the first analysis of Dunn \& Dunn's learning style theory and four factors for the second analysis of the Honey and Mumford's learning style theory. The use of factor analysis for both groups of variables resulted in extraction of three distinct factors for the first group of variables and four distinct factors for the second group of variables.

Figure 5: Scree plot for the first factor analysis - Dunn \& Dunn's learning style theory

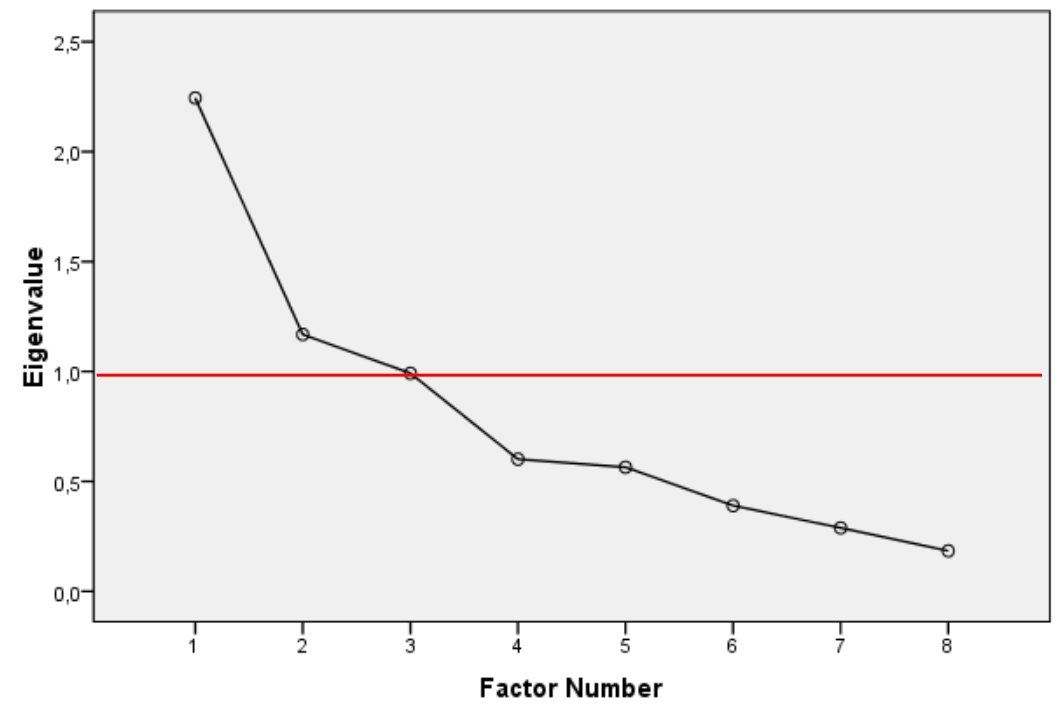

Source: Authors. 
Figure 6: Scree plot for the second factor analysis - Honey and Mumford's learning style theory

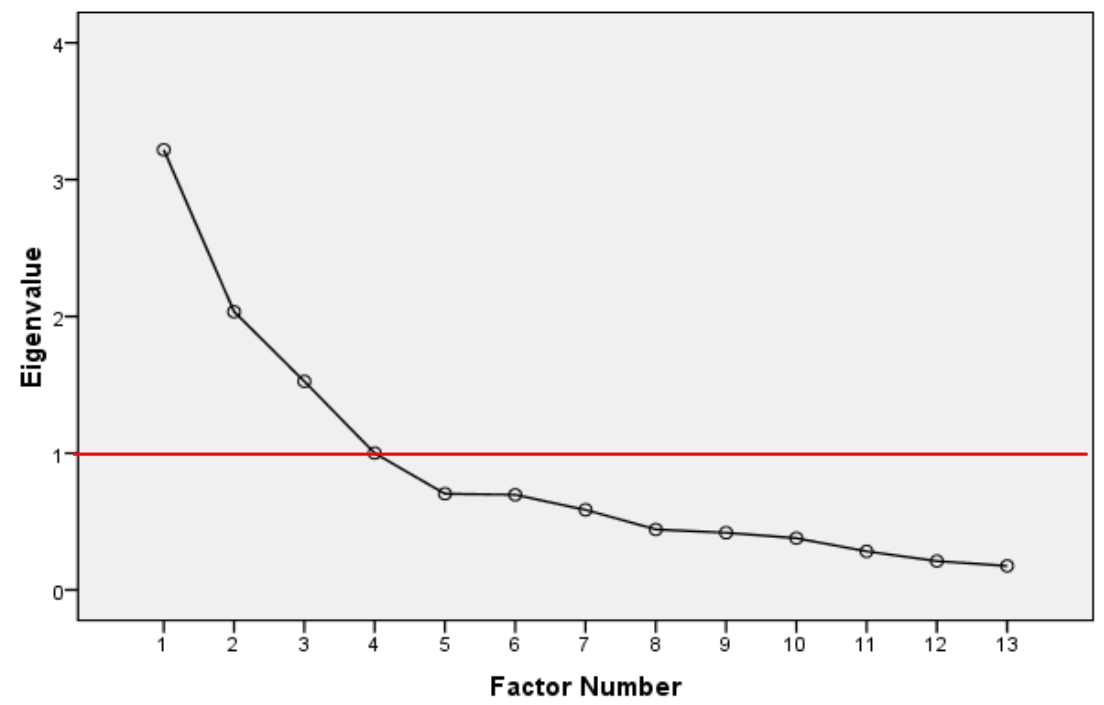

Source: Authors.

The factors extracted from the fist group of variables were labelled as visual (best explaining two variables $\mathrm{Vp} 1, \mathrm{Vp} 6$ ), auditory (best explaining two variables $\mathrm{Vp} 2, \mathrm{Vp} 7$ ) and kinaesthetic (best explaining four variables Vp8, Vp9, Vp3 and Vp10) confirming the Dunn \& Dunn's learning style theory (VAK) and the factors extracted from the second group of variables were labelled reflectors (best explaining three variables Vs3, Vs6, Vs11), theorists (best explaining three variables Vs10, Vs4, Vs1), activists (best explaining two variables Vs5, Vs9), pragmatists (best explaining five variables Vs7, Vs12, Vs13, Vs14, Vs15) confirming the applicability of the Honey and Mumford's learning style questionnaire theory (LSQ). The factor numeric definition of individual variables is indicated in tables below (Table 4 and Table 5): In both factor analyses individual factors have significant loadings (greater than \pm 0.30 ) on all variables. Variables defined by individual factors are indicated with red frames for both factor analyses. 
Table 4: Factor loadings before and after rotation - Dunn \& Dunn's learning style theory

\begin{tabular}{|c|c|c|c|c|c|c|}
\hline & \multicolumn{3}{|c|}{$\begin{array}{c}\text { Raw } \\
\text { Factor }\end{array}$} & \multicolumn{3}{|c|}{$\begin{array}{c}\text { Rescaled } \\
\text { Factor }\end{array}$} \\
\hline & 1 & 2 & 3 & Kinaesthetic & Visual & Auditory \\
\hline Vp1 &,- 053 & ,690 & ,000 &,- 069 & ,906 & ,000 \\
\hline Vp6 & ,031 & ,401 &, 065 &, 033 & ,426 & ,069 \\
\hline $\mathrm{Vp} 2$ &,- 072 & ,132 & ,570 &,- 100 &, 183 & ,790 \\
\hline Vp7 & , 169 &,- 032 & ,559 &, 180 &,- 034 & .597 \\
\hline Vp8 & ,283 &,- 064 & ,077 &, 532 &,- 119 &, 144 \\
\hline Vp9 & 655 & ,211 & ,091 & 649 & ,209 & ,090 \\
\hline Vp3 & ,827 & ,048 &,- 030 & ,760 &, 044 &,- 028 \\
\hline Vp10 & 692 &,- 094 &,- 030 & ,664 &,- 090 &,- 029 \\
\hline
\end{tabular}

Extraction Method: Principal Axis Factoring.

Rotation Method: Varimax with Kaiser Normalization.

a. Rotation converged in 4 iterations.

Source: Authors.

Figure 7: Distribution of variables in rotated 3D factor space - Dunn \& Dunn's learning style theory

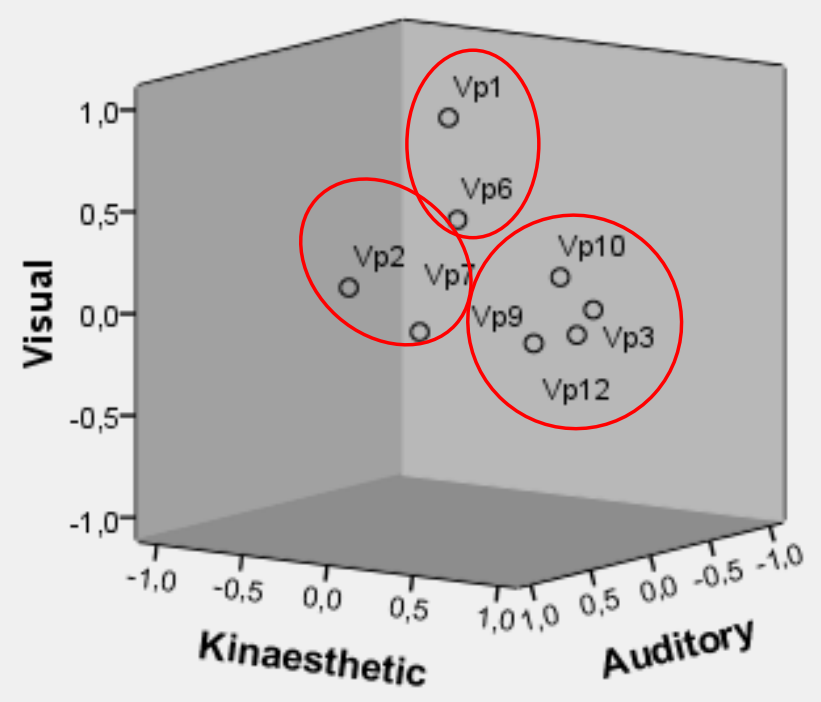

Source: Authors. 
Table 5: Factor loadings before and after rotation - Honey and Mumford's learning style theory (LSQ)

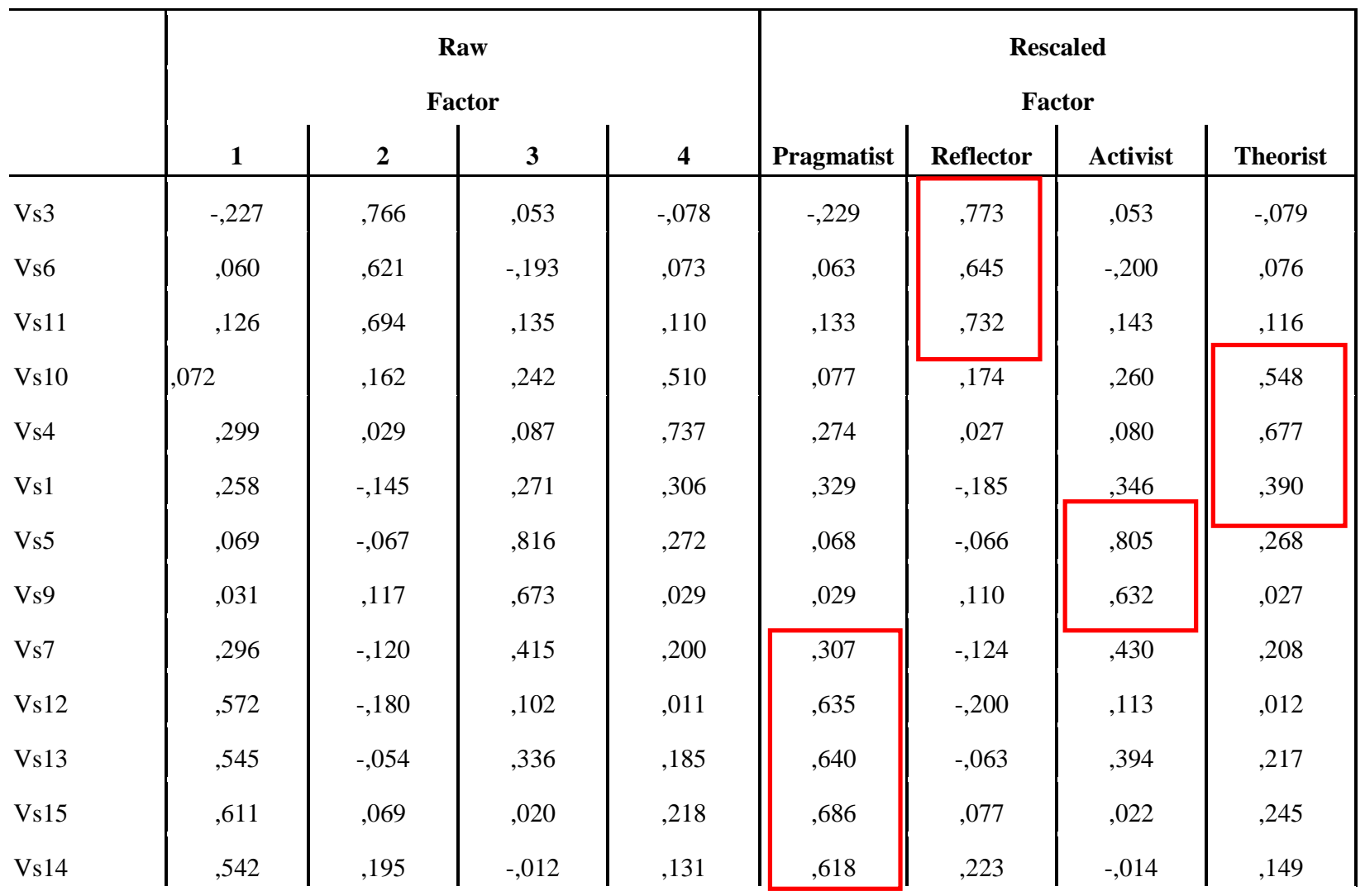

Extraction Method: Principal Axis Factoring.

Rotation Method: Varimax with Kaiser Normalization.

a. Rotation converged in 5 iterations.

Source: Authors.

\subsection{Reliability Of The Compounded Scales}

Cronbach's Alpha measures how well a set of items (or variables) measures a single unidimensional latent construct. In order to assess the reliability of compound scales (the extracted factors) measuring applied learning styles concepts the Cronbach Alpha Coefficient was calculated for the sample as a whole and for both factor analyses (see Table 6). Technically speaking, Cronbach's Alpha is not a statistical test rather it is a coefficient of reliability (or consistency), the reliability coefficient $\alpha$ of 0,7 or higher is considered "acceptable" in most social science research situations (Coakes \& Steed, 2003). As indicated the results of both factor analyses are close to satisfactory: Factors extracted from the first factor analysis have Cronbach Alpha values from 0,603 to 0,729, factors for the second factor analysis have Cronbach Alpha values from 0,630 to 0,744. These results indicate that the extracted factors appropriately characterize the dimensionality of the data. 
Table 6: Reliability (Cronbach Alpha Coefficient)

\begin{tabular}{l|l|r|}
\hline \hline Factor analysis & \multicolumn{1}{|c}{ Factors } & Cronbach Alpha \\
\hline \hline \multirow{2}{*}{ Dunn \& Dunn's learning style theory } & Kinaesthetic &, 729 \\
& Visual &, 545 \\
& Auditory &, 603 \\
\hline \hline & Pragmatist &, 744 \\
Honey and Mumford's learning style theory & Reflector &, 743 \\
& Activist &, 688 \\
& Theorist &, 630 \\
\hline
\end{tabular}

Source: Authors.

\subsection{T-test}

The objective of running t-tests is to statistically determine whether means from two independent samples are different. In the next step t-tests for all factors of both factor analyses were performed (the values of the extracted factors were used for this purpose, which is why some mean values are negative). T-tests were run twice for all factors from both factor analyses: in the first running, the variable gender was used as a grouping variable, in the second running, year of study was the grouping variable. The results confirm the male students' learning approach is more pragmatic and theoretic than female students' approach. Women seem to use more reflector and activist learning styles. However, the differences are not, following statistical criteria, conclusive enough (only the difference in 'theorist' component is statistically significant $\mathrm{p}=0,033<0,05$ ). The difference of learning approaches between males and females when applying the Dunn \& Dunn's learning style theory is even less conclusive. This can also be stated for differences between second and third year students when applying either of learning styles theories. In general, the classification according to either of both applied learning theories seems to be independent of the socio-demographic variables gender and year of study. The choice of individual's learning styles seems to be based upon the individual's mental and cultural constitution and not his/her socio-demographic characteristics.

\section{DISCUSSION AND IMPLICATIONS}

\subsection{The Results And Conclusion}

The aim of this study is was to compare and explore two widely used learning styles theories in higher education system at the University of Ljubljana, Faculty of Economics (FELU) in Slovenia (see Figure 8 for summary of results and implications). By analyzing the 2nd and 3rd year Faculty of Economics students' learning approaches typical patterns have been discovered. The research confirmed the results through qualitative metaanalysis and quantitative factor analysis. Analyses resulted in a clear extraction of three theoretically expected learning styles dimensions according to Dunn and Dunn's learning style theory (factors - visual, auditory and kinaesthetic) in the first factor analysis which confirmed the logic/applicability of the Dunn and Dunn's learning styles theory. Furthermore, study resulted in a in a clear extraction of four theoretically expected learning styles dimensions (factors - reflectors, theorists, activists, pragmatists) in the second factor analysis which confirmed the logic/applicability of the Honey and Mumford's learning style theory. The analysis of correlation between extracted factors of both learning styles theories indicates that both theories are independent of each other. The results of ttests probing the difference between mean values of extracted factors indicate that learning styles are insensitive to socio-demographic influences (gender and year of study). All these results indicate that both applied theories are very robust for the sampled population: Each student is unique in their approach to learning, i.e. he/she can follow, with equal probability, any combination of learning styles explained by two applied theories and the choice of a learning style is not influenced by the gender and the level of knowledge (year of study). The individual's choice of learning style is obviously based on personal/inner impulse rather than socio-demographic conditions. The secondary objective of the study, to develop valid and reliable research questionnaire for further research, has been 
reached only partially. The questionnaire was developed to get the first of learning styles in national higher education system and was significantly influenced by (1) the small sample size and (2) its focus on probing the validity of two chosen learning style theories. The questionnaire as it is designed now is appropriate for an introductory research on a small sample size.

Figure 8: Implications for Educators on Learning Style Theories in Higher Education Institutions

The Results and Implications

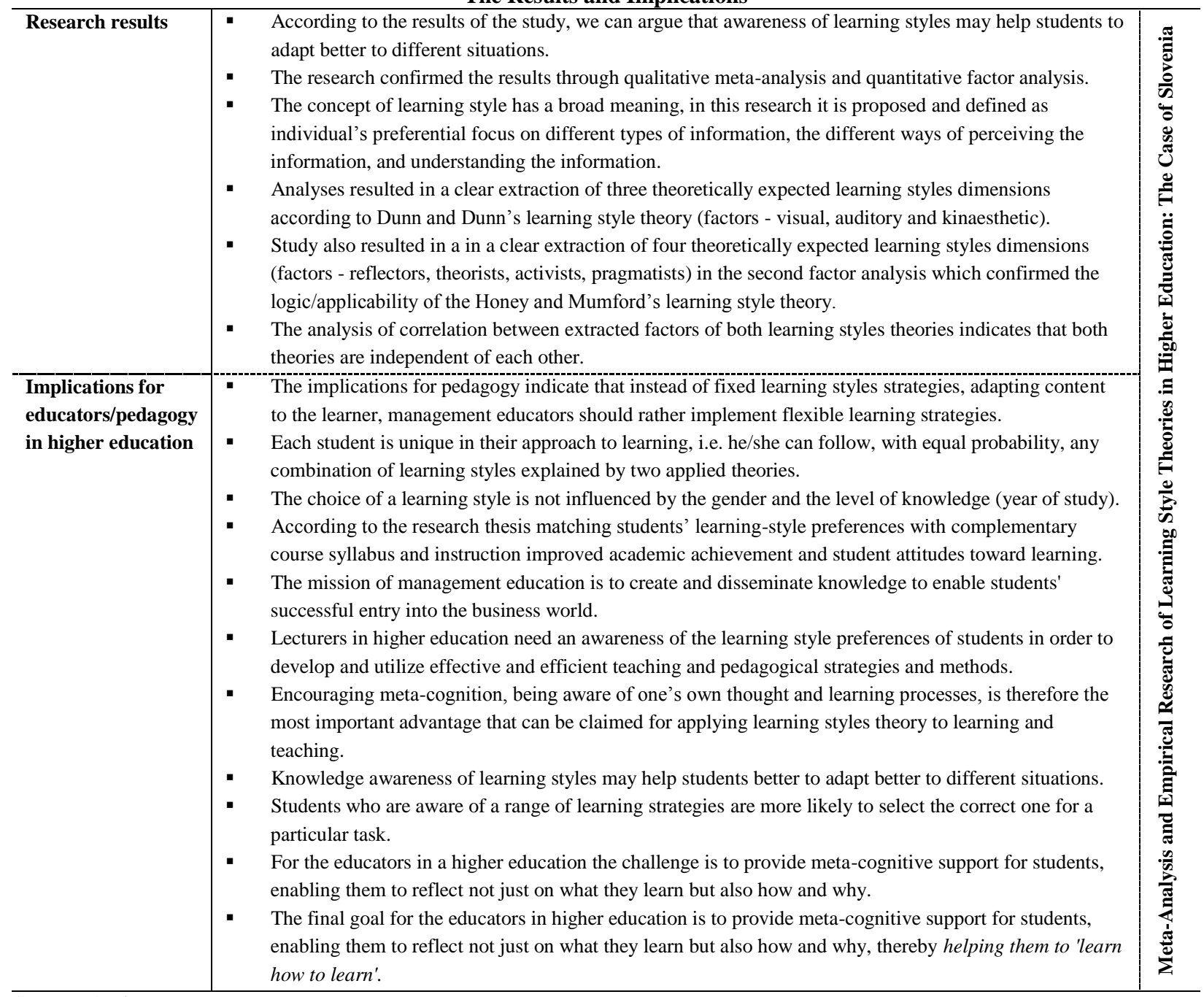

Source: Authors.

According to the research thesis of this study we can summarize that matching students' learning-style preferences with complementary course syllabus and instruction improved academic achievement and student attitudes toward learning. The mission of management education is to create and disseminate knowledge to enable students' successful entry into the business world and offer a rewarding investment opportunity to the business community. The development of these new skills and knowledge requires a variety of teaching methods and learning strategies in order to match students' learning styles preferences. Therefore, lecturers in higher education need an awareness of the learning style preferences of students in order to develop and utilize effective and efficient teaching and pedagogical strategies and methods. A significant number of researchers (Kolb, 1999; Honey \& Mumford, 
1992; Armstrong \& Mahmud, 2008) have argued that learning styles are not determined by inherited characteristics, but develop through experience. Styles are therefore not necessarily fixed, but can change over time, even from one situation to the next. Theorists such as Entwistle $(1998,2002)$, on the other hand, are more interested in how students tackle a specific learning task/learning strategy than any habitual preference/learning style. What these authors have in common is an emphasis not simply on the learner but on the interaction between the learner, the context and the nature of the task. If, therefore, learning styles are not fixed personality traits, the emphasis shifts from accommodating learning styles to encouraging a balanced approach to learning and, perhaps more importantly, an explicit awareness of the range of approaches available to the learner. Even among authors who question the validity of learning styles as a concept (Coffield et al., 2004), most agree that there is a benefit in enabling learners to reflect on how they learn. Encouraging meta-cognition, being aware of one's own thought and learning processes, is therefore perhaps the most important advantage that can be claimed for applying learning styles theory to learning and teaching.

According to the results of the study, we can argue that knowledge awareness of learning styles may help students better to adapt better to different situations. The implications regarding the learning strategies implementation in management education suggest that students who are aware of a range of learning strategies are more likely to select the correct one for a particular task. The implications for pedagogy indicate that instead of fixed learning styles strategies, adapting content to the learner, management educators should rather implement flexible learning strategies. The approach of flexible learning style strategy is best suited to the case-study method of teaching. For the educators in a higher education institution, the challenge is to provide meta-cognitive support for students, enabling them to reflect not just on what they learn but also how and why.

\subsection{Limitations And Future Research}

The research here is subject to a few limitations. (1) It is based on one educational program at one university, and it should be generalized by having data from several institutions. Data should be collected from multiple institutions with a larger sample size. (2) Besides the sample is based on only second and third year students and it should cover all four years of study in order to have a general view of education. (3) The most prominent deficiency of the research is that it does not recognize the dimension of time. Namely the concept of this research is inherently static. In general recognizing students' learning styles allows educators to effectively instruct a diverse population of students. According to the results of this research, one could easily conclude that the teaching approach should consider the results of this analysis by mirroring the learning techniques of individual learning styles as these learning styles seem to be fixed. This conclusion could easily be reached as the results of the research are very robust. But, knowing that, in contrast to this research, a significant number of researchers (Kolb, 1999; Honey \& Mumford, 1992; Armstrong \& Mahmud, 2008) have argued that learning styles are not determined by inherited characteristics, but develop through experience. Therefore, further analysis should focus on determining those developments - styles are not necessarily fixed, but can change over time, even from one situation to the next.

\section{CONCLUSION}

"A university should, I believe, provide an experience of living as well as opportunity for learning”

(Sloman 1964; in Sievers, 2007)

The objective of this paper was to better understand the different learning styles among management students enrolled in the course Economics of Education in order to develop appropriate teaching and pedagogical strategies for improving management education at the Faculty of Economics in Ljubljana, Slovenia. Besides, the research was intended to help developing valid and reliable research questionnaire for further research processes. The adapted version of Honey and Mumford's (1992) Learning Style Questionnaire (LSQ) and Dunn \& Dunn's (2003) VAK Learning Style Theory (Coffield et al., 2004) were used as an instrument in the questionnaire to determine Slovenian students' learning style.

The concept of learning style has a broad meaning, in this research it is proposed and defined as individual's preferential focus on different types of information, the different ways of perceiving the information, 
and understanding the information (Li et al., 2008). The learning styles literature has had a revival during last years, especially in the first decade of 21st century (Alban \& Metcalfe 2002; Duff \& Duffy, 2002; Dunn \& Griggs, 2003; Kayes, 2003; Loo, 2004). Upon reviewing the literature on learning styles, the intense rate and growing interest is involved. The aim of this study was to present and explore the learning styles of students enrolled in the course Economics of education during March and April 2008 in Slovenia at University of Ljubljana, Faculty of Economics (FELU) - Department of management and organization. The FELU has a long tradition in research and education as it was founded in 1946. Today, it is the largest faculty of the University of Ljubljana with almost 10,000 full-time and part-time undergraduate and graduate students. Although learning styles have been heavily researched, little is known about Slovenian students' learning styles, especially in the field of management education.

The research generated the results through qualitative meta-analysis and quantitative factor analysis. By analyzing the 2nd and 3rd year Faculty of Economics students' learning approaches, typical patterns have been confirmed: analyses resulted in clear extraction of three theoretically expected learning styles dimensions according to Dunn and Dunn's learning style theory (factors - visual, auditory and kinaesthetic) in the first factor analysis which confirmed the logic/applicability of the Dunn and Dunn's learning styles theory and four theoretically expected learning styles dimensions (factors - reflectors, theorists, activists, pragmatists) in the second factor analysis which confirmed the applicability of the Honey and Mumford's learning style theory. Recent thinking in this area suggests that unlike cognitive personality styles, learning styles can be modified to a degree through learning and training strategies. Instead of matching training to the styles of the learners it could be more rewarding to expose learners to a mismatched learning environment in order to help them develop a wider repertoire of coping behaviours and learning strategies. Those that can learn to use a variety of problem-solving and learning strategies, and apply them in situations that do not match with their natural learning style, may be more able to perform effectively across a wider range of situations than those who have limited stylistic versatility (Hayes \& Allinson, 1996). Kolb (1984) also acknowledged the potential longer term value of intentionally mismatching to increase adaptability, help learners overcome weaknesses in their learning style, and develop a more integrated approach to learning.

The implications for pedagogy indicate that instead of fixed learning styles strategies, adapting content to the learner, management educators should rather implement flexible learning strategies. The implications regarding the learning strategies implementation in management education suggests that students who are aware of a range of learning strategies are more likely to select the correct one for a particular task. The mission of management education is to create and disseminate knowledge to enable students' successful entry into the business world and offers a rewarding investment opportunity to the business community. The ultimate goal for the educators in higher education institution is to provide meta-cognitive support for students, enabling them to reflect not just on what they learn but also how and why, thereby helping them to 'learn how to learn'. Further studies are expected to follow and support this objective and the appropriate research instrument would be developed for this purpose. This introductory research could be an appropriate starting point. According to the results of the study, we can argue that awareness of learning styles may help students to adapt better to different situations. The implications regarding the learning strategies implementation in management education suggest that students who are aware of a range of learning strategies are more likely to select the correct strategy for a particular task.

\section{AUTHOR INFORMATION}

Sandra Penger, Ph.D., is research and teaching assistant at the Department of Management and Organization at the Faculty of Economics, University of Ljubljana (http://www.ef.uni-lj.si/en/). Her research interests are in economics of education, positive organizational behavior, authentic leadership, organizational identity, learning organization and new public management. She attended many international conferences, where she presented papers in her research area and published several articles in Slovene, European, and US journals. More information at http://www.ef.uni-lj.si/pedagogi/pedagog.asp?id=301, http://www.futureo.si/; or via e-mail: sandra.penger@ef.unilj.si.

Metka Tekavčič, Ph.D., is an associate professor at the Department of Management and Organization at the Faculty of Economics, University of Ljubljana (http://www.ef.uni-lj.si/en/). She is the Head of the Institute of Management 
and Organization. Her research interests are in cost management, performance measurement, economics of education and new public management. She attended many international conferences, where she presented papers in her research area and published several articles in Slovene, European, and US journals. She is a member of editorial boards in several professional journals from her research field. More information at http://www.ef.unilj.si/pedagogi/pedagog.asp?id=67, or via e-mail: metka.tekavcic@ef.uni-lj.si.

Vlado Dimovski, Ph.D., is full professor at the Department of Management and Organization at the Faculty of Economics, University of Ljubljana (http://www.ef.uni-lj.si/en/). He is also the Head of Department of Management and Organization at the Faculty. His research interests are in organizational learning, management, organizational behavior and leadership. His studies on knowledge management and organizational learning culture, using structural model and meta-analysis techniques for performance improvement relating to the Slovenian and Eastern Europe data assessment, are published in SCIE journals in the field of management, information technology, industrial and organizational behavior. More information at http://www.ef.uni-lj.si/pedagogi/pedagog.asp?id=65; http://www.futureo.sil; or via e-mail: vlado.dimovski@ef.uni-lj.si.

\section{REFERENCES}

1. Alban-Metcalfe, J. (2002). Attention deficit/hyperactivity Disorder type Behaviors among Undergraduates and their Relation to Learning Style. Research in Education, 68, 89-109.

2. Alkhasawneh, I. M, Mrayyan, M. T., Docherty, C., Alashram, S. \& Yousef, H. Y. (2008). Problem-Based Learning (PBL): Assessing Students' Learning Preferences Using Vark. Nurse Education Today, 28(5), 572-579.

3. Allinson, C. W. \& Hayes, J. (1990). Validity of the Learning Styles Questionnaire. Psychological Report, 67, 859-866.

4. Argyris, C. (2007). Double-Loop Learning in Classroom Setting. In Reynolds M \& Vince R. (Ed.), the Handbook of Experiential Learning \& Management Education. Oxford: Oxford University Press.

5. Armstrong, S. \& Mahmud, A. (2008). Experiential Learning and the Acquisition of Managerial Tacit Knowledge. Academy of Management Journal, 7(2), 189-208.

6. Brewerton, P. \& Millward Lynne. (2001). Organizational Research Methods. London: Sage Publications.

7. Champoux, J. E. (2007). Experiential Learning in the On-Line Environment: Enhancing On-Line Teaching and Learning. In Reynolds M \& Vince R. (Ed.), the Handbook of Experiential Learning \& Management Education. Oxford: Oxford University Press.

8. Coakes, S. J. \& Steed, L. G. (2003). SPSS Analysis without Anguish, Version 11.0 for Windows. Milton: Wiley.

9. Coffield, F., Moseley, D., Hall, E. \& Ecclestone, K. (Ed.). (2004). Learning Styles and Pedagogy in post-16 Learning: A Systematic and Critical Review. Wiltshire: Learning and Skills Research Centre.

10. Constantinidou, F. \& Baker, S. (2002). Stimulus Modality and Verbal Learning Performance in Normal Aging. Brain and Language, 82(3), 296-311.

11. Cuthbert, P. F. (2005). The student learning process: Learning styles or Learning Approaches? Teaching in Higher Education, 10(2), 235- 249.

12. Dart, B. C., Burnett, P. C., Puride, N., Boulton-Lewis, G., Campbell, J. \& Smith, D. (2000). Students' Conceptions of Learning, the Classroom Environment, and Approaches to Learning. The Journal of Educational Research, 93(4), 262-270.

13. Demirbas, O. O. \& Demirkan, H. (2007). Learning Styles of Design Students and the Relationship of Academic Performance and Gender in Design Education. Learning and Instructions, 17, 345-359.

14. Dimovski, V. \& Škerlavaj, M. (2004). Organizational Learning and Information-Communication Technologies-A Promising Link. Journal of Economics and Business, 22(1), 7-21.

15. Dimovski, V., Škerlavaj, M., Kimman, M. \& Hernaus, T. (2008). Comparative Analysis of the Organisational Learning Process in Slovenia, Croatia, and Malaysia. Expert Systems with Applications, 34 (4), 3063-3070.

16. Duff, A. \& Duffy, T. (2002). Psychometric Properties of Honey 6 Mumford's Learning Style Questionnaire (LSQ). Personality and Individual Differences, 22, 147-163. 
17. Duff, A., Dobie, A. \& Guo, X. (2008). The Influence of Business Case Studies and Learning Styles in an Accounting Course: A Comment. Accounting Education, 17(2), 129-144.

18. Dunn, R. \& Griggs, S. (2003). Synthesis of the Dunn and Dunn Learning Style Model Research: Who, What, When, Where, and What? New York: St. Johns' University Press.

19. Dunn, R. (2001). Learning Style: State of the Science. Theory into Practice, 13(1), 10-19.

20. Dunn, R. (2003). The Dunn and Dunn Learning Style Model: Theoretical Cornerstone, Research and Practical Applications. In Armstrong S. \& Graff M. (Ed.), Bringing Theory and Practice, Proceedings of the $8^{\text {th }}$ Annual European Learning Styles Information Network Conference. Hull: University of Hull.

21. Ellinger, A. D. \& Doctoral Students. (2007). Experiencing Scholarly Writing through A Collaborative Course Project. In Reynolds M \& Vince R. (Ed.), the Handbook of Experiential Learning \& Management Education. Oxford: Oxford University Press.

22. Entwistle, N. J. (1998). Improving Teaching through Research on Student Learning. In Forrest, J. J. F (Ed.), University teaching: International Perspectives. New York: Gerland.

23. Ferligoj, A., Leskošek, K. \& Kogovšek, T. (1995) Zanesljivost in veljavnost merjenja. Metodološki zvezki. Ljubljana, 11, 173.

24. Garcia, P., Amandi, A., Schiaffino, S. \& Campo, M. (2007). Evaluating Bayesian Networks’ Precision for Detecting Students' Learning Styles. Computers \& Education, 49, 794-808.

25. Herbert, A., Stenfors, S. (2007). Choosing Experiential Methods for Management Education: The Fit of Action Learning and Problem-Based Learning. In Reynolds M \& Vince R. (Ed.), the Handbook of Experiential Learning \& Management Education. Oxford: Oxford University Press.

26. Honey, P. \& Mumford, A. (1992). The Manual of Learning Styles. Maidenhead: Peter Honey Publications.

27. Honey, P. \& Mumford, A. (1992). The Manual of Learning Styles. Maidenhead: Peter Honey.

28. Hyde, P. (2007). Integrating Experiential Learning through Live Projects. In Reynolds M \& Vince R. (Ed.), the Handbook of Experiential Learning \& Management Education. Oxford: Oxford University Press.

29. Kanji, G. P. (1993). 100 Statistical Tests. London: Sage Publications.

30. Kayes, A. B. (2007). Power and Experience: Emancipation through Guided Leadership Narratives. In Reynolds M \& Vince R. (Ed.), The Handbook of Experiential Learning \& Management Education. Oxford: Oxford University Press.

31. Kayes, D. C. (2007). Institutional Barriers to Experiential Learning Revisited. In Reynolds M \& Vince R. (Ed.), The Handbook of Experiential Learning \& Management Education. Oxford: Oxford University Press.

32. Kayes, D. D. (2002). Experiential Learning Theory and its Critics: Preserving the Role of Experience in Management Learning and Education. Academy of Management Learning and Education, 1(2), 137-149.

33. Kolb, D. A. (1976). Learning Style Inventory: Technical Manual. Boston: McBer \& Company.

34. Kolb, D. A. (1984). Experiential Learning: Experience as the Source of Learning and Development. NJ: Prentice Hall.

35. Kolb, D. A. (1999). The Kolb's Learning Styles Inventory. Boston: Hay Group.

36. Lhori-Posey, B. (2003). Determining Learning Styles of Students. Nurse Educator, 28(2), 54.

37. Li, Y. S, Chen, P. S. \& Tsai, S. J. (2008). A Comparison of the Learning Styles among Different Nursing Programs in Taiwan: Implications for Nursing Education. Nurse Education Today, 28, 70-76.

38. Loo, R. (2004). Kolb's learning styles and learning preferences: is there a linkage? Educational Psychology, 24(1), 99-108.

39. Metallidou, P. \& Platsidou, M. (2008). Kolb's Learning Style Inventory-1985: Validity Issues and Relations with Metacognitive Knowledge about Problem-solving Strategies. Learning and Individual Differences, 18(1), 114-119.

40. Miller, R. L., Acton, C., Fullerton D. A. \& Maltby J. (2002). SPSS for Social Scientists. Briston: Palgrave Macmillan.

41. Nicolini, D., Gherardi, S. \& Yanow, D. (2003). Knowing in Organizations - A Practice Based Approach. Armonk, NY: M. E. Sharpe.

42. Peters, D., Jones, G. \& Peters, J. (2008). Preferred 'learning styles' in Students Studying Sports-Related Programmers in Higher Education in the United Kingdom. Studies in Higher Education, 3(2), $155-166$.

43. Rourke, B., Ahmad S., Collins, D., Hayman-Abello, B., Hayman-Abello, S., \& Warriner, E. (2002). Child Clinical/Pediatric Neuropsychology: Some Recent Advances. Annual Review of Psychology, 53, 309339. 
44. Sievers, B. (2007). Pictures from Bellow the Surface of the University: The Social Photo-Matrix as a Method for Understanding Organizations in Depth. In Reynolds M \& Vince R. (Ed.), the Handbook of Experiential Learning \& Management Education. Oxford: Oxford University Press.

45. Škerlavaj, M. \& Dimovski, V. (2006). Social Network Approach to Organizational Learning. Journal of Applied Business Research, 22(2), 89-97.

46. Škerlavaj, M. \& Dimovski, V. (2007). Towards Network Perspective of Intra-organizational Learning: Bridging the Gap between Acquisition and Participation Perspective. Interdisciplinary Journal of Information, Knowledge and Management, 2, 43-58.

47. S Škerlavaj, M., Indihar Štemberger, M., Škrinjar, R. \& Dimovski, V. (2007). Organizational learning Culture - the missing link between business process change and organizational performance. International Journal of Production Economics, 106, 346-367.

48. Tseng, J. C. R., Chu, H. C., Hwang, G. J., Tsai, C.C. (2008). Development of an Adaptive Learning System with Two Sources of Personalization Information. Computers \& Education, 51(2), 776-786.

49. Welsh, M.A., Dehler, G. E. \& Murray, D. L. (2007). Learning about and Through Aesthetic Experience: Understanding the Power of Experience-Based Education. In Reynolds M \& Vince R. (Ed.), the Handbook of Experiential Learning \& Management Education. Oxford: Oxford University Press.

\section{NOTES}




\section{NOTES}

